\title{
STRATEGIC CUSTOMER ANALYSIS BASED ON BALANCED SCORECARD
}

\author{
Sergey Krylov ${ }^{1, \mathrm{a}, *}$ \\ ${ }^{1}$ Ural Federal University, Academic Department of Accounting, Analysis and Audit, Mira 19, 620002 \\ Ekaterinburg, Russian Federation \\ azali6770@yandex.ru \\ *Corresponding author
}

Cite as: Krylov, S. (2019). Strategic customer analysis based on balanced scorecard. Ekonomickomanazerske spektrum, 13(1), 12-25.

Available at: dx.doi.org/10.26552/ems.2019.1.12-25

\begin{abstract}
The balanced scorecard is one of the well-trialled management instruments that are familiar to all market participants in the world. The paper considers theoretical aspects of the applied strategic customer analysis based on the customer element of the balanced scorecard to be applied in the research process of the strategic organization distribution activity aspects and its sales management. The methodology of the research is the balanced scorecard concept as well as the concept of the applied strategic analysis concept having been developed by the author. The applied strategic customer analysis is depicted to encompass comparative assessment, variances diagnostics and indicators forecast of the customer balanced scorecard element within the strategic customer goals. It encompasses analysis of customer profitability level, analysis of products distribution market share, analysis of customer base volume, composition and structure, and analysis of customer demands satisfaction degree. The applied strategic customer analysis results in the ability to be employed for the long-term, medium and short-term management decisions in the field of the organization distribution activity in conditions of the modern world economy. The methodology instruments of the applied strategic customer analysis comprise an aggregate of techniques (ways, methods) to facilitate handling the essential problems of the analysis accomplished and, respectively, its goal reached. The basic methods of the applied strategic customer analysis include techniques of absolute, relative and average values, comparison, grouping, graphics and table methods, correlation-regression analysis, factoring analysis, cluster analysis and expert evaluation methods. The author draws a conclusion that the applied strategic customer analysis is a sufficiently effective instrument to research strategic aspects of the organization distribution activity and to form analytical support for its strategic sales management in a present-day economic environment.
\end{abstract}

Keywords: applied strategic customer analysis, balanced scorecard, distribution activity, organization

JEL Classification: L19, M19, M41, O12

\section{Introduction}

In present-day economic environment, a long-term sustained development of an organization (enterprise, firm, company, business entity) ensuring its utmost market value assumes satisfying the requirements of stakeholders, customers being the most important of them. 
The customers expect their organization to meet their ultimate demands. They anticipate the organization performance to reach a certain acceptable level corresponding to the image, products quality, delivery dates and price-to-quality ratio.

A need for taking account of the customers' expectations mentioned in the strategic organization distribution activity, i.e. sales, transforms them into the appropriate strategic customer element goal of the balanced scorecard (BSC) setting, firstly, a direction for the organization activity and enabling it to understand market research structure, customers research process, products planning, their promotion and distribution, and pricing planning as well. Secondly, it ensures that each organization subdivision seeks to reach well-defined objectives interrelated with the overall organizational goals. Thirdly, it encourages coordination of various functional directions efforts. Fourthly, the BSC customer element causes the organization to assess its strengths and weakness from their rivals' standpoint, opportunities and threats within the environments. Fifthly, this BSC element specifies alternative actions or combinations to be undertaken by the organization. Sixthly, it sets the base for the resources allocation. Seventhly, it demonstrates the importance of the performance assessment procedure applied.

However, it is worthwhile as to assess a degree of certain strategic decisions accomplishments in the field of the sales management as to find out the cause of the variance (if any) and to forecast the situation development, the whole and the parts facilitate the development and improvement of the appropriate analytical tools.

In view of the mentioned above, the author of the paper seeks to consider his applied strategic analysis to be employed in the process of the analytical support development for strategic sales management.

Meanwhile, we have to take into account the researches having been done by some wellknown scientists and specialists in the field in terms of the BSC analysis application as a whole, the customer element being non-emphasized.

So, R.S. Kaplan and D.P. Norton, the balanced scorecard concept co-founders, treat such factors, facilitating the strategy review and discussion, as correlations and causations analysis, organizational learning at the executive level followed by the scenario analysis, reported examples, strategic initiatives analysis and independent expert assessments (Kaplan and Norton, 1996). They believe a contradiction between the planned and the actual encourages executives to think of strategy adequacy. Should new consumer value offering introduced into targeted market segment result in higher customer and financial element indicators? Are the processes of new products and services development and promotion appreciated by customers fast enough? In addition, R.S. Kaplan and D.P. Norton state that balanced scorecard forms "theory of enterprise" differing favourably from other efficiency evaluation systems. The wellworked integrated scores system at the managers' disposal enables them to check their business strategy if non-statistically but formally.

The researchers from Hovarth \& Partners believe the BSC analysis to provide answers for the following main questions (Hovarth \& Partners, 2004): How successful is strategic goals accomplishment (basing on real indicators values)? What are the reasons for real indicators values variances from targeted ones? How are strategic events being implemented? Which events are we able to implement? Which company divisions have demonstrated substantial variances from targeted ones? How do developing trends influence strategy translation success? Who analyses a state of strategy translation: a division manager or a team of experts?

M.G. Brown thinks an analysis to compute and further research of so-called analytical BSC scores values (Brown, 2007). He assumes analytical indicators as sensors on organization management board informing executives about the efficiency of their efforts. However, these 
numbers, statistical values or estimates, are different from those of most corporations' indicators system. The analytical indicators are oriented on a certain efficiency component added from sub-indicators (lower level indicators being different variables and frequently measured in different units) reflecting a separate direction of your activity. Each sub-indicator included in the analytical indicator is weighted depending on its importance for the assessment of efficiency, reliability and probability. According to M.G. Brown, the system based on the analytical indicators provides more complete performance efficiency estimation than system based on separate individually measured indicators. The analytical indicators are generally measured by the 100-score scale, 100 being the largest figure. In the course of analysis based on the results of the analytical indicators computations, they state a cause of the level or a trend of efficiency. The main reason for having caused problems or efficiency decline is to be included. The arguments and reasons for higher efficiency or trends for enhancement should be documented. The analysis is to result in a plan of actions for the development of measures needed to raise efficiency or to support it at the level reached. The plan of actions generally comprises objectives, list of personalities responsible for their attainments and schedules. It should be noted that the plan takes account of the analytical information. The plan of actions is commonly developed by the manager responsible for the indicator deteriorated.

Under H.K. Rampersad, the analysis is to be targeted at stating the organization successes and failures as well as finding out an extent of the set targets reached (Rampersad, 2003). Depending on the extent of the set targets correspondence to the results, achieved balanced scorecard translation and formulation could be corrected. The analysis is to be aimed at permanent BSC agreement with changing environment. The latter creates an effect of learning that facilitates a better understanding of an organization its own processes. H.K. Rampersad thinks, that a likely analysis at the level of organization and individual employees will foster a process of learning as a whole.

H.R. Friedag and W. Schmidt consider BSC analysis is to deal with indicators deviating from the planned ones and seek answers for the following: Are there contingencies, do your employees cope with, is your plan proper? A process of strategy translation must be discussed at the enterprise every month (Friedag and Schmidt, 2002).

N.G. Olve, J. Roy and V. Wetter point out that regular BSC indicators measurements and analysis do not need to be arranged; an ideal management control implies a mere checking procedure or generalizing index dynamics control (Olve et al., 2000).

\section{Methodology}

The methodology of the research, the results being presented in the paper, is based on the following concepts:

1. The balanced scorecard concept (BSC);

2. The applied strategic analysis concept (ASA).

The balanced scorecard concept as an analytical instrument applied in the field of strategic management was developed by American scientists Robert Kaplan and David Norton at the beginning of the 90s of the XX century (1992). It evolved further by both in their works (Kaplan, 2005, 2008) , (Kaplan and Norton, 1993, 1996, 2004, 2005, 2006, 2008), (Kaplan et al., 2010) and those of other scientists studying economics (Brown, 2007), (Friedag and Schmidt, 2002), (Horvath and Partners, 2004), (Hu et al., 2017), (Inderst and Ottaviani, 2013), (Maisel, 1992), (Messeghem et al., 2018), (Niven, 2014, A), (Niven, 2014, B), (Niven, 2014, C), (Okongwu et al., 2015), (Olve et al., 2000), (Ozmantar and Gedikoglu, 2016), (Rampersad, 2003), (Rasolofo-Distler and Distler, 2018), (Shrinkle, 2012), (Villas-Boas, 2007), (Witcher 
and Butterworth, 2001), (Zhang et al., 2015), and was multiply tested. Today BSC is considered to be one of the essential and sufficiently effective facilities ensuring strategic organization management.

It should be noted, that the main reason to develop BSC was a contradiction between contingencies aimed at setting up wider competitive opportunities and immobile accounting (financial accounting) system (Kaplan and Norton, 1996).

The balanced scorecard as a whole is understood as an aggregate of parameters featuring an overall organization performance in the present-date market economy. It reflects a balance to be brought about between short-term and long-term goals, financial and non-financial indicators, basic and auxiliary parameters, as well as internal and external factors of the organization economic activity (Kaplan and Norton, 1992).

The scores of the balanced scorecard system are specially formed depending on the outlook and strategic goals of any particular organization. They represent a balance between external accounting data for the owners (shareholders), and customers and internal characteristics of the most significant business processes, innovations, training, and growth. That is the balance between the results of the organization performance and future growth. The system comprises a combination of objectives quantitatively estimated data and subjective somewhat arbitrary parameters of future growth (Kaplan and Norton, 1993).

The main goal of the balanced scorecard is to transform a company strategy into specific tangible objectives, indicators and end up with events (Niven, 2014, A).

The BSC scores are selected so that the organization managers and employees focus on the factors to enhance the organization competitiveness (Hu et al., 2017). The BSC should be accessible in terms of information for the employees of all levels. The 'front-end' employees are to be well aware of the financial consequences of their decisions and actions. Meanwhile, the top managers must be committed to the long-term financial success (Rasolofo-Distler \& Distler, 2018).

The balanced scorecard is founded on the cause and effect links, results attain factors and their interrelation with financial data (Maisel, 1992).

The balanced scorecard encompasses four basic interrelated elements: finance, a customer, internal business processes ones as well as training and personal development element considered through the prism of key problems, strategic goals, indicators and their target values and strategic events as well (Messeghem et al., 2018), (Okongwu et al., 2015).

The BSC scores enable to characterize comprehensively a performance of both commercial and government, and non-profit organizations, the scores being relatively few (about 25 scores in average, as a rule) (Kaplan and Norton, 1996), (Ozmantar and Gedikoglu, 2016).

The development of the applied strategic analysis concept was caused by the need to enhance strategic management efficiency in difficult conditions of the present-day market economy, to improve its information-analytical support, thereby stipulating an expediency of further evolution of theory, methodology and methods of the overall strategic organization performance aspects to the level of the financial analysis at least being a sufficiently effective research instrument of the financial aspects of the organization economic activity based on the financial indicators (Krylov, 2010).

ASA, as a strategic management function, assumes overall research of the strategic organization performance aspects based on the BSC (Krylov, 2013). Basing on the balanced scorecard system special for any particular organization, the applied strategic analysis lacks any standard methods. The ASA methods are special as well for any particular organization.

The goal of the applied strategic analysis implementation is to form analytical support for making strategic management decisions. 
The essential ASA objectives are the following (Krylov, 2014, A):

1. Comparative assessment of the BSC scores assumes a comparison of their outcome and target figures, determination of the balanced scorecard real and target figures variance and qualitative evaluation of the variances.

2. Diagnostics of the BSC indicators variances enables to find out the results attaining factors having an impact on the general or outcome BSC indicators and determine the variance value by means of the appropriate methods of the factoring analysis.

3. Balanced Scorecard forecast of the purposeful nature implies a primordial determination and/or correction of the target BSC scores values and either determination of the specific ways of their attainment or the development of the events aimed at the elimination of the variance emerged between outcome and target BSC scores values in the future.

All the objectives are interrelated as each consecutive objective follows from the previous one: the diagnostics is exercised by the results of the BSC elements comparative assessment while their forecast takes into account the results of the diagnostics. Three interrelated and agreed applied strategic analysis aspects stand out:

1. A strategic aspect proper, within the aspect evaluated, diagnosed and forecast are final BSC indicators values for the time period of the developed strategy in effect, i.e. their strategic values.

2. A tactical aspect, within the aspect evaluated, diagnosed and forecast are interim BSC indicators values by the end of the year, i.e. their tactical values.

3. An operational aspect, within the aspect evaluated, diagnosed and forecast are interim BCS indicators values by the end of each month, i.e. their operational values.

The results of the analysis of the operational BSC indicators values impact on their tactical values and the results of the tactical value analysis influence the strategic ones. The basic ASA technique comprises methods of absolute, relative and average values, comparison, grouping, graphical and table methods, correlation and regression analysis, factoring analysis, cluster analysis, as well as an expert evaluation method.

The applied strategic analysis is accomplished by deduction that presumes, firstly, an investigation of the general BSC indicators, then specific ones, and defines the general sequence of the ASA analysis according to the following leads: financial indicators analysis, customer indicators analysis, internal business-processes indicators analysis, training and personnel development indicators analysis. In addition, each of the basic ASA leads, financial, customers, internal business processes as well as training and personal development is represented through the prism of its basic objectives: evaluation, diagnostics and forecast. Following the approach, the ASA commences from the comparative evaluation of the financial indicators and is completed by the forecast of training and personal development. The basic leads of applied strategic analysis mentioned above can be transformed into separate groups:

1. Applied strategic financial analysis.

2. Applied strategic customer analysis.

3. Applied strategic analysis of internal business-processes (comprising applied strategic analysis of after-sales service, applied strategic performance (operational) analysis and applied strategic innovative analysis).

4. Applied strategic analysis of training and personal development.

When describing the ASA contents as a complex category of economics in his previous works the author has assumed the applied strategic analysis (ASA) to be a kind of the applied strategic analysis presuming overall complex research of the strategic aspects of the organization innovative activity based on the innovative balanced scorecard element (Krylov, 
2014, B), (Krylov \& Ilysheva, 2016) and the applied strategic financial analysis (ASFA) implying overall complex research of the organization financial activity by the financial element of its balanced scorecard (Krylov, 2015), (Krylov and Ilysheva, 2017). In the present paper, the author considers the following kind of ASA - an applied strategic customer analysis.

\section{Results}

\subsection{Concept and essence of the applied strategic customer analysis}

An applied strategic customer analysis (ASCA), a kind of the applied strategic analysis, assumes a complex, comprehensive research of the strategic organization distribution activity aspects basing on the customer element of its balanced scorecard. It can also be taken as a facilitating function of strategic sales management. The ASCA subject is the customer BSC element indicators (customer indicators) and the factors specifying them and the object is strategic organization distribution activity aspects. The goal of the applied strategic financial analysis is to form analytical support of making strategic decisions in the field of sales performance management. To attain the ASCA goal mentioned its most important objectives (analogous to the BSC ones) are to be reached, such as comparative assessment, diagnostics variances, and forecast of the balanced scorecard customer element. All the objectives of the applied strategic customer analysis are closely interrelated since each subsequent objective follows from the previous one: the diagnostics of the customer BSC element indicators variances is exercised by the results of their comparative assessment and the indicators forecast are derived from their diagnostics variances results. Comparative assessment of the balanced scorecard customer element implies a comparison of their real and target figures, finding corresponding variances and their qualitative characteristics (Table 1). The qualitative characteristics of the BSC customer element real and target figures variance depend largely on their value (Table 2). The diagnostics of the balanced scorecard customer element indicators variance is based on the cause and effect links combining BSC values, the customer element included, into the balanced complex of general indicators and their specifying factors (results attaining factors).

Table 1: A form of analytical table to exercise comparative assessment of the BSC customer element

\begin{tabular}{cccccc}
\hline $\begin{array}{c}\text { Name of the } \\
\text { BSC } \\
\text { customer } \\
\text { element }\end{array}$ & $\begin{array}{c}\text { Target figure of } \\
\text { the BSC } \\
\text { customer element } \\
\text { indicator }\end{array}$ & $\begin{array}{c}\text { Real figure of the } \\
\text { BSC customer } \\
\text { indicator }\end{array}$ & $\begin{array}{c}\text { element indicator } \\
\end{array}$ & $\begin{array}{c}\text { Variance of the BSC customer } \\
\text { elemt indicator real figure } \\
\text { from the target one }\end{array}$ & $\begin{array}{c}\text { Qualitative } \\
\text { variance } \\
\text { characteristic of } \\
\text { the BSC customer } \\
\text { element indicator }\end{array}$ \\
\hline
\end{tabular}

Source: compilation by author

Table 2: Exemplary qualitative estimation of the variance characteristics of the BSC customer element's real and target figures

\begin{tabular}{cc}
\hline $\begin{array}{c}\text { Real figure variances values of the BSC customer elemen } \\
\text { from the target ones, } \\
\%\end{array}$ & $\begin{array}{c}\text { Qualitative estimation of the BSC customer element real } \\
\text { figure from their target ones }\end{array}$ \\
Up to 1 & Fairly small \\
From 1 to 5 & Essential \\
From 5 to 10 & Significant \\
From 10 to 20 & Large \\
20 and higher & Very large \\
\hline
\end{tabular}

Source: (Krylov, 2014, A) 
While diagnosing the BSC customer element indicators variance found are the results attaining factors, which are mostly impacting on the general or outcome indicators of the Balanced Scorecard customer element, and determined is its value.

It should be noted that the outcome customer indicators of more specific BSC elements (internal business-processes, personnel training and development) could be considered as factors determining factoring indicators variances of more general customer element. So, a factoring model of the balance scorecard customer element indicators comprises the outcome BSC customer element indicators as final (the most general) ones and five levels of the defining factors:

1-st level factors: factoring BSC customer element indicator;

2-nd level factors: some outcome indicators of the BSC internal business processes, personal development and training;

3-rd level factors: some factoring indicators of the BSC internal business processes, personal training and development;

4-th level factors: some outcome indicators of the BSC personnel training and development;

5-th level factors: some factoring indicators of the BSC personnel training and development.

The computation results of the factoring indicators impact on the outcome BSC customer elements indicators defined are presented in the form of a table (Table 3).

Table 3: A form of analytical table to show computation results of the factors impact on the outcome BSC customer element indicators variance

\begin{tabular}{|c|c|c|c|c|c|c|c|c|c|}
\hline \multirow{3}{*}{$\begin{array}{l}\text { Outcome BSC customer } \\
\text { element indicator }\end{array}$} & \multirow{3}{*}{$\begin{array}{l}\text { Absolute variance } \\
\text { value of the outcome } \\
\text { BSC customer } \\
\text { element indicator }\end{array}$} & \multicolumn{8}{|c|}{ Factoring indicators impact } \\
\hline & & & st level & & $\ldots$ & & & $5^{\text {th }}$ level & \\
\hline & & $\ldots$ & $\ldots$ & $\ldots$ & $\ldots$ & $\ldots$ & $\ldots$ & $\ldots$ & $\ldots$ \\
\hline
\end{tabular}

Source: compilation by author

The corresponding deductions are drawn from the computation results and imply either primordial establishment or adjustment of the target BSC customer indicators values (in case of the objective conditions) and determination of the specific methods of their attainment or the development of the events aimed at the elimination of the variance emerged between outcome and target values of the BSC customer element indicators in the future. In addition, the forecast commences with the general (outcome) indicators, the factoring ones being derived from them.

The results of the forecast of the BSC customer element indicators values are presented in the form of a table (Table 4).

Table 4: A Form of an analytical table to present the results of the BSC customer element indicators values forecast

\begin{tabular}{ccccc}
\hline $\begin{array}{c}\text { Name of the BSC } \\
\text { customer element } \\
\text { indicator }\end{array}$ & $\begin{array}{c}\text { Absolute real } \\
\text { value of the BSC } \\
\text { customer element } \\
\text { indicator }\end{array}$ & $\begin{array}{c}\text { Target value } \\
\text { of the BSC } \\
\text { customer element } \\
\text { indicator }\end{array}$ & $\begin{array}{c}\text { Target value variance from the } \\
\text { real value of the BSC customer } \\
\text { element indicator }\end{array}$ & Comments \\
\cline { 3 - 4 } & & absolute & $\%$ \\
\hline
\end{tabular}

Source: the table was developed by the author

To the aspects of the ASCA as a kind of ASA referred are a strategic aspect proper, tactical aspect and operational aspect. 
Within the scope of the strategic aspect of the applied strategic customer analysis estimated, diagnosed and forecast are final BSC customer element indicators for the time-period of the developed customer (distribution) strategy functioning, i.e., their strategic values.

Within the frame of the tactical aspect of the applied strategic customer analysis estimated, diagnosed and forecast are interim BSC customer element indicators by each year end, i.e., their tactical values.

Within the scope of the operational aspect applied strategic customer analysis estimated, diagnosed and forecast are interim BSC customer element indicators by the end of each month, i.e., their operational values.

It should be noted, that all the ASCA aspects mentioned are interrelated and agreed: the results of the operational BSC customer element indicators values analysis make an impact on their tactical values and the results of the analysis of the tactical values- on the strategic ones.

The ASCA methodology instruments comprise an aggregate of techniques (ways, methods) to facilitate handling the essential problems of the analysis accomplished and, respectively, its goal reached. The basic methods of the applied strategic customer analysis include techniques of absolute, relative and average values, comparison, grouping, graphics and table methods, correlation-regression analysis, factoring analysis, cluster analysis and expert evaluation methods.

\subsection{Information base of the applied strategic customer analysis}

The ASCA information base is the customer BSC element (Table 5), the formation comprising a number of steps: definition of the strategic customer process goal, construction of the strategic customer process map, selection of the customer indicators, definition of the target customer indicators values, development of the strategic customer events.

Table 5: Balanced scorecard customer element of the organization development

\begin{tabular}{|c|c|c|c|c|}
\hline $\begin{array}{l}\text { Key problem of the balanced } \\
\text { scorecard customer element }\end{array}$ & $\begin{array}{c}\text { Strategic } \\
\text { customer goal }\end{array}$ & $\begin{array}{c}\text { Customer element } \\
\text { indicator }\end{array}$ & Target value & $\begin{array}{c}\text { Strategic customer } \\
\text { event }\end{array}$ \\
\hline $\begin{array}{l}\text { What goals concerning structure } \\
\text { customer demands do they have to } \\
\text { attain financial goals? }\end{array}$ & & & & \\
\hline
\end{tabular}

Source: compilation by author

The strategic customer goals and measurements of their indicators, on the one hand, specify financial goals and measurement of their indicator, on the other, they are basic to define goals and indicators of the two other BSC elements: internal business-processes and personnel training and development ones.

In spite of the strategic customer goals being special and separate for each organization within specific conditions of time and location we consider a number of strategic customer goals universal for any type of organization, as an example:

1. ensuring customer demands satisfied;

2. retaining existing customer base;

3. building up customer base;

4. capturing the certain market segment;

5. ensuring maximum customer profitability.

The attainment of each previous strategic customer goal facilitates further goals to be reached. So the fifth strategic customer goal - ensuring maximum customer profitability - must 
be treated as the basic strategic customer goal while the four ones are considered as rather specific ones.

Consider, as an example, certain general customer indicators measuring their five strategic customer goals mentioned above (ensuring customer demands satisfied; retaining existing customer base; building up existing customer base; capturing certain market share; ensuring maximum customer profitability) and bring them together into Table 6.

Table 6: Certain general indicators of the BSC customer element indicators

\begin{tabular}{|c|c|}
\hline Strategic customer goal & Measuring indicators \\
\hline \multirow{3}{*}{ Ensuring customer demands satisfied } & Suppliers rating defined by customer \\
\hline & Customer questioning results \\
\hline & Number of repeat transactions with the same customers \\
\hline \multirow{3}{*}{ Retaining existing customer base } & Number of permanent customers and/or their share in the overall figure \\
\hline & $\begin{array}{c}\text { Number of transactions with permanent customers and/or their share in the total } \\
\text { deals. }\end{array}$ \\
\hline & $\begin{array}{l}\text { Sales volume to permanent customers and/or their share in the overall sales. } \\
\text { Customer number growth on absolute and/or per-unit basis. }\end{array}$ \\
\hline \multirow[t]{2}{*}{ Building up customer base } & $\begin{array}{l}\text { Transactions number growth on absolute and/or per-unit basis. } \\
\text { Sales volume growth on absolute and/or per-unit basis. }\end{array}$ \\
\hline & $\begin{array}{l}\text { Actual new customer's ratio to number of prospects found during the questionin } \\
\text { run after advertising campaign. }\end{array}$ \\
\hline Canturing certain market share & Market share of the company \\
\hline capturmg certam mákel smäe & Shares of separate consumers. \\
\hline \multirow{2}{*}{ Ensuring maximum customer profitability } & Overall net sales to sales revenue ratio \\
\hline & Net sales to sales revenue ration to separate consumers. \\
\hline
\end{tabular}

Source: compilation by author

The target values of the customer indicators must be rigorous but fully achievable. The target values of the customer indicators in terms of methods are determined by means of preliminary development further disputed and agreed at the meetings and combined with the building of the business-plan model. However, the following principle has to be obeyed: a balance of the strategic customer goals is to be reflected by the balance of the target values describing them.

The strategic customer events are assumed as the events relevant to the strategic customer goals determined for the balanced scorecard customer element. The strategic customer events enable to specify the strategic customer goals and link the customer strategy with customer managers' operational objectives. Thereby the key idea of the balanced scorecard customer element is realized, i.e. a transfer of the customer strategy into specific customer management actions since the BSC customer element commences its performance as soon as the strategic customer events are implemented. As regards the strategic customer events, such operations, may encounter as entering new distribution markets or other events irrelevant to the customer operational activity demanding substantial resources. Other events, such as long-term promotion campaign or investment in attractiveness of the trademark can be attributed to the group.

\subsection{Components and sequences of the applied strategic customer analysis execution}

The applied strategic customer analysis as a kind of the applied strategic analysis is carried out in compliance with the principle of deduction encompassing research firstly, general indicators of the BSC customer element then specific ones.

The basic components of the ASCA are the following:

1. Analysis of customer profitability level.

2. Analysis of products distribution market share.

3. Analysis of customer base volume, composition, and structure.

4. Analysis of customer demands satisfaction degree. 
The overall sequence of the applied strategic customer analysis is built on the principle of the analysis mentioned above and its basic elements.

The procedure of the applied strategic customer analysis execution commences from the analysis of customer profitability level. It is followed by the analysis of products distribution market share, captured by the organization. Later the analysis of customer base volume, composition, the structure is carried out. Finally, we analysed a degree of customer demands satisfaction.

A more detailed process of the ASCA analysis execution can be presented through the prism of its main objectives i.e. comparative assessment, diagnostics of the variance and the forecast of the BSC customer element.

Considering the customer element indicators to be grouped into the outcome and factoring ones the applied strategic customer analysis starts with the comparative assessment of the outcome indicators characterizing a level of customer profitability and is completed with the forecast of the factoring indicators of a degree of customer demands satisfaction.

In addition, assuming "intersection points" of the analyzed BSC customer element indicators and the most important objectives of the applied strategic customer analysis being defined as some kind of the ASCA components we are able to build a matrix (Table 7).

Table 7: Matrix of the ASCA components

\begin{tabular}{cccc}
\hline Basic ASCA & Major ASCA objectives (j) & Diagnostics of \\
\cline { 2 - 4 } components (i) & $\begin{array}{c}\text { Comparative assessment of } \\
\text { BSC scores } \\
\text { (1) }\end{array}$ & $\begin{array}{c}\text { DSC scores variances } \\
\text { (2) }\end{array}$ & $\begin{array}{c}\text { Forecast of } \\
\text { BSC scores } \\
\text { (3) }\end{array}$ \\
\hline $\begin{array}{c}\text { Analysis of customer } \\
\text { profitability level (1) }\end{array}$ & $\begin{array}{c}\text { Comparative assessment of } \\
\text { customer profitability level. }\end{array}$ & $\begin{array}{c}\text { Diagnostics of customer } \\
\text { profitability level variances }\end{array}$ & $\begin{array}{c}\text { Forecast of customer } \\
\text { profitability level. }\end{array}$ \\
$\begin{array}{c}\text { Analysis of products } \\
\text { distribution market shar } \\
(2)\end{array}$ & $\begin{array}{c}\text { Comparative assessment of } \\
\text { products distribution market } \\
\text { share }\end{array}$ & $\begin{array}{c}\text { Diagnostics of products } \\
\text { distribution market share } \\
\text { variances }\end{array}$ & $\begin{array}{c}\text { Forecast of products } \\
\text { distribution market share }\end{array}$ \\
$\begin{array}{c}\text { Analysis of customer ba: } \\
\text { volume, composition, an } \\
\text { structure (3) }\end{array}$ & $\begin{array}{c}\text { Comparative assessment of } \\
\text { customer base volume, } \\
\text { composition, and structure. }\end{array}$ & $\begin{array}{c}\text { Diagnostics of customer base } \\
\text { volume, composition, and } \\
\text { structure variances. }\end{array}$ & $\begin{array}{c}\text { Forecast of customer base } \\
\text { volume, composition, and } \\
\text { structure }\end{array}$ \\
$\begin{array}{c}\text { Analysis of customer } \\
\text { demands satisfaction } \\
\text { degree (4) }\end{array}$ & $\begin{array}{c}\text { Comparative assessment of } \\
\text { customer demands satisfaction } \\
\text { degree. }\end{array}$ & $\begin{array}{c}\text { Diagnostics of customer demanc } \\
\text { satisfaction degree variances. }\end{array}$ & $\begin{array}{c}\text { Forecast of customer demand } \\
\text { satisfaction degree }\end{array}$ \\
\hline
\end{tabular}

Source: compilation by author

Denoting elements of the matrix as $c_{i j}(i=1,2,3,4 ; j=1,2,3)$, enables mathematically to describe the ASCA content by means of the formulae:

$$
C=\sum_{i=1}^{4} \sum_{j=1}^{3} c_{i j}
$$

where $\quad C \quad$ is an amount of the ASCA elements

$i \quad$ is an index of the ASCA elements: 1 is the analysis of customer profitability level; 2 is the analysis of products distribution market share; 3 is the analysis of customer base volume, composition, and structure; 4 is the analysis of customer demands satisfaction degree

$j \quad$ is an index of major ASCA objectives: 1 is the comparative assessment of the BSC customer element; 2 is diagnostics of the BSC customer element variances; 3 is the forecast of the BSC customer element 
The author of the paper considers the matrix (Table 7) and the formulae (1) as a matrix and mathematical model of ASCA, respectively, visualizing their composition and economic contents. Examples of the outcome and factoring indicators analysed per every complex ASCA element are presented in Table 8.

Table 8: Examples of analyzed outcome and factoring indicators per each ASCA component

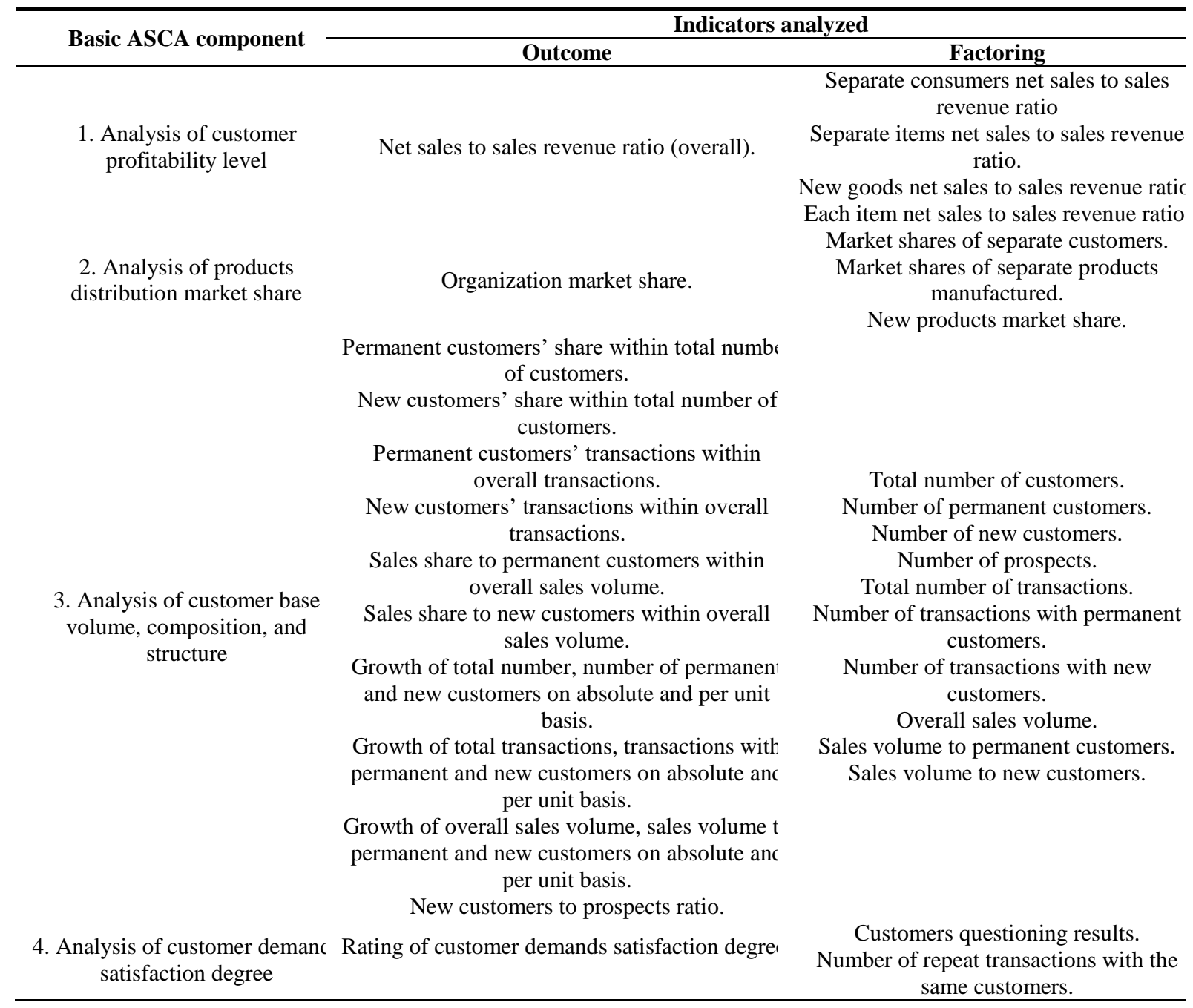

Source: compilation by author

\section{Discussion}

The author insists the results of the research, undertaken to develop the applied strategic analysis concept as the research instrument of the strategic organization distribution activity aspects and sales management, based on the balanced scorecard customer element, to carry no analogy and to be considered as new and unique ones.

Generalizing succinctly the statements of the leading scholars in the field of the balanced scorecard mentioned above it is worth isolating a number of key moments concerning essence of the analysis based on it:

Goals of BSC based analysis imply successfulness assessment of organization strategy translation and continued BSC agreement with changing environment; 
Analysis presumes determination of real BSC indicators values variances from targeted (planned) ones, bring their causes out and find out organization divisions with substantial variances;

The analysis enables learning of so-called analytical (generalizing) indicators of organization performance efficiency calculated at weighted average based on specific BSC indicators estimated by 100 -score scale;

Analysis results assume a plan of actions to develop measures for raising organization performance efficiency or supporting it at the level achieved and continued learning effect facilitating a better understanding for an organization its own processes.

Thus, the statements of some well-known scientists dealing with the balanced scorecard problem mentioned above carry evidence that they lack a clear well-defined BSC analysis exercise concept including its separate elements the customer one as well. Some general desires concerning the contents and analysis execution are presented. The author of the paper proposes a clear, well-defined conceptual approach for carrying out an applied strategic customer analysis as a kind of the applied strategic analysis having been developed by the author (Krylov, $2010,2013,2014$, A) enabling to enhance a strategic management efficiency of the organization distribution activity.

Unlike other researchers mentioned above the author has worked out the methodical aspects of the applied strategic customer analysis (analytical tables forms, recommendations to evaluate a degree of the factoring BSC customer indicators variances from the targeted ones, a factorial analysis graph model of the variances arisen, constituting a block-scheme as well) and provides the examples of the outcome and factoring BSC customer indicators analysed.

The author considers the building of so-called analytical indicators basing on the BSC scores to be inexpedient as a technique of their computations at the weighted average is of subjective nature and deteriorates the analysis results accuracy rather than improves it.

Thus the author's vision and solution of the problem treated in the paper is more detailed, well-thought and visualized compared with other researchers mentioned above (R.S. Kaplan and D.P. Norton; specialists from Hovarth and Partners; M.G. Brown; H.K. Rampersad; H.R. Friedag and W. Schmidt; N.G. Olve, J. Roy and V. Wetter).

\section{Conclusion}

Completing a consideration of the applied strategic customer analysis, a number of conclusions are drawn: Applied strategic customer analysis is a new and sufficiently efficient instrument to research strategic aspects of the organization distribution activity forming analytical support of the strategic sales management;

Its methodology constitutes concepts of the balanced scorecard and applied strategic analysis;

ASCA presumes comparative assessment, variances diagnostics and forecast of the BSC customer element indicators of the organization within its strategic customer goals;

ASCA comprises the analysis of customer profitability level, analysis of products distribution market share, analysis of customer base volume, composition and structure, and analysis of customer demands satisfaction degree;

ASCA commences from the comparative assessment of outcome indicators, characterizing customer profitability level and is completed by factoring indicators forecast of customer demands satisfaction degree; 
Results of applied strategic customer analysis may be applied for the development and implementation decisions of long-term, medium-term and short-term character in the field of sales management.

Funding: This research received no external funding

Author Contributions: The author confirms being the sole contributor of this work and approved it for publication.

Conflict of Interest Statement: The author declares that the research was conducted in the absence of any commercial or financial relationships that could be construed as a potential conflict of interest.

\section{References}

Brown, M. G. (2007). Beyond the balanced scorecard. Improving business intelligence with analytics. New York: Productivity Press.

Friedag, H. R. \& Schmidt, W. (2002). Balanced scorecard: Mehr als ein kennzahlensystem. Berlin: Haufe Mediengruppe.

Horvath \& Partners. (2004). Balanced scorecard umzetzen. Stuttgart: Schaeffer-Poeschel Verlag GmbH.

Hu, B., Leopold-Wildburger, U. \& Strohhecker, J. (2017). Strategy map concepts in a balanced scorecard cockpit improve performance. European Journal of Operational Research, 258(2), 664-676.

Inderst, R. \& Ottaviani, M. (2013). Sales talk, cancellation terms and the role of consumer protection. Review of Economic Studies, 80(3), 1002-1026.

Kaplan, R. S. (2005). How the balanced scorecard complements the McKinsey 7-s model. Strategy and Leadership, 33(3), 41-46.

Kaplan, R. S. (2008). Conceptual foundations of the balanced scorecard. Handbook of Management Accounting Research, 3, 1253-1269.

Kaplan, R. S. \& Norton, D. P. (1992). The balanced scorecard: Measures that drive performance. Harvard Business Review, 70(1), 71-79.

Kaplan, R. S. \& Norton, D. P. (1993). Putting the balanced scorecard to work. Harvard Business Review, 71(5), 134-142.

Kaplan, R. S. \& Norton, D. P. (1996). The balanced scorecard: Translating strategy into action. Boston: Harvard Business School Press.

Kaplan, R. S. \& Norton, D. P. (2004). Measuring the strategic readiness of intangible assets. Harvard Business Review, 82(2), 52-63.

Kaplan, R. S. \& Norton, D. P. (2005). The office of strategy management. Harvard Business Review, 83(10), 7280.

Kaplan, R. S. \& Norton, D. P. (2006). Alignment. Using the balanced scorecard to create corporate synergies. Boston: Harvard Business School Press.

Kaplan, R. S. \& Norton, D. P. (2008). The execution premium: Linking strategy to operations for competitive advantage. Boston: Harvard Business School Press.

Kaplan, R. S., Norton D. P. \& Rugelsjoen, B. (2010). Managing alliances with the balanced scorecard. Harvard Business Review, 88(1-2 SI), 114-120.

Krylov, S. I. (2010). Razvitie metodologii analiza v sbalansirovannoi sisteme pokazatelei [Development of analysis's methodology in the balanced scorecard]. Moscow: Finance and Statistics.

Krylov, S. (2013). Applied strategic analysis as further balanced scorecard concept development. Proceedings of the $11^{\text {th }}$ Eurasia Business and Economics Society (EBES) Conference. Ekaterinburg, Russia, 35-42.

Krylov, S. I. (2014, A). Theoretical aspects of economic balanced scorecard analysis. Asian Journal of Finance \& Accounting, 6(1), 90-109.

Krylov, S. (2014, B). Applied strategic innovative analysis: Theoretical aspects. European Journal of Business and Social Sciences, 3(3), 113-133.

Krylov, S. (2015). Applied strategic financial analysis within strategic management of organization finance. European Journal of Business and Management, 7(15), 1-16. 
Krylov, S. \& Ilysheva, N. (2016). Integrated management analysis of innovation performance in conditions of globalization. Proceedings of the $16^{\text {th }}$ International Scientific Conference on Globalization and Its SocioEconomic Consequences. Rajecke Teplice, Slovak Republic, 734-740.

Krylov, S. \& Ilysheva, N. (2017). Strategic financial analysis based on balanced scorecard in present-day economic environment. Proceedings of the $17^{\text {th }}$ International Scientific Conference on Globalization and Its SocioEconomic Consequences. Rajecke Teplice, Slovak Republic, 1194-1201.

Maisel, L. S. (1992). Performance management: The balanced scorecard approach. Journal of Cost Management, $6(2), 47-52$.

Messeghem, K., Bakkali, C., Sammut, S. \& Swalhi, A. (2018). Measuring nonprofit incubator performance: Toward an adapted balanced scorecard approach. Journal of Small Business Management, 56(4), 658-680.

Niven, P. R. (2014, A). Create a balanced scorecard of robust measures, meaningful targets, and strategic initiatives. Hoboken, NJ: John Wiley \& Sons Inc., 221-267.

Niven, P. R. (2014, B). Integrating change management techniques to drive balanced scorecard success, Hoboken, NJ: John Wiley \& Sons Inc., 327-339.

Niven, P. R. (2014, C). Let everyone demonstrate their contribution by cascading the balanced scorecard, Hoboken, NJ: John Wiley \& Sons Inc., 305-326.

Okongwu, U., Brulhart, F. \& Moncef, B. (2015). Causal linkages between supply chain management practices and performance: A balanced scorecard strategy map perspective. Journal of Manufacturing Technology Management, 26(5), 678-702.

Olve, N.-G., Roy, J. \& Wetter, V. (2000). Performance drivers: A practical guide to using the balanced scorecard. Chichester: John Wiley \& Sons, Ltd.

Ozmantar, Z. K. \& Gedikoglu, T. (2016). Design principles for the development of the balanced scorecard. International Journal of Educational Management, 30(5), 622-634.

Rampersad, H. K. (2003). Total Performance Scorecard: Redefining Management to Achieve Performance with Integrity. New York, NY: Butterworth Heinemann.

Rasolofo-Distler, F. \& Distler, F. (2018). Using the balanced scorecard to manage service supply chain uncertainty: Case studies in French real estate services. Knowledge and Process Management, 25(3), 129-142.

Shrinkle, G. A. (2012). Organizational aspirations, reference points, and goals: Building on the past and aiming for the future. Journal of Management, 38(1), 415-455.

Villas-Boas, S. B. (2007). Vertical relationships between manufacturers and retailers: Inference with limited data. Review of Economic Studies, 74(2), 625-652.

Witcher, B. J. \& Butterworth, R. (2001). Hoshin Kanri: Policy management in Japanese-owned UK subsidiaries. Journal of Management Studies, 38(5), 651-674.

Zhang, X., Zhong, W. \& Makino, S. (2015). Customer involvement and service firm internationalization performance: An integrative framework. Journal of International Business Studies, 46(3), 355-380. 